Sains Peternakan Vol. 6 (2), September 2008: 1-9

ISSN 1693-8828

\title{
Studi Potensi Sampah dan Kandungan Residu Logam Berat pada Produk Sapi Potong yang Digembalakan di TPA Sampah "PUTRI CEMPO" Surakarta
}

\author{
E. Handayanta \\ Jurusan Peternakan, Fakultas Pertanian, Universitas Sebelas Maret \\ Jl. Ir. Sutami 36 A, Kentingan, Surakarta \\ Email: ekahandayanta@yahoo.com
}

\section{INTISARI}

Penelitian ini bertujuan untuk mengetahui potensi sampah (jumlah dan kualitas) sebagai sumber pakan sapi potong serta kandungan residu logam berat $\mathrm{Pb}$ dan $\mathrm{Hg}$ pada produk sapi potong yang digembalakan di lokasi TPA sampah "Putri Cempo" Surakarta.

Penelitian dilaksanakan di TPA sampah "Putri Cempo" Surakarta sebagai tempat pengambilan sampel sampah khususnya jumlah dan kualitas sampah organik dan pengambilan sampel sapi potong untuk diketahui kandungan logam berat $(\mathrm{Pb}$ dan $\mathrm{Hg}$ ) pada daging, hati, ginjal dan usus.

Hasil penelitian menunjukkan bahwa jumlah sampah organik yang di buang di TPA "Putri Cempo" Surakarta Tahun 2002 - 2006 rata-rata sebesar 47,778 - 54,372 ribu ton per tahun, sedangkan kandungan nutriennya masing-masing Protein Kasar (PK) : 10,00 - 12,79\%, Lemak Kasar (LK) : 4,05 - 7,94\%, Serat Kasar (SK) : 18,42 - 22,20\%, dan Abu : 21,73-24,33\%. Kandungan logam berat pada daging, hati, ginjal dan usus masing-masing, $\mathrm{Pb} 2,16-2,68 \mathrm{ppm}$ (di atas SNI 2,0 ppm), sedangkan $\mathrm{Hg} \mathrm{0,01} \mathrm{-0,02} \mathrm{(di} \mathrm{bawah} \mathrm{SNI} \mathrm{0,03} \mathrm{ppm).}$

Kesimpulan dari penelitian ini adalah bahwa TPA sampah "Putri Cempo" Surakarta memiliki potensi yang besar sebagai tempat penggembalaan sapi potong. Disisi lain, produk sapi yang digembalakan di TPA kurang aman dikonsumsi karena kandungan Pb-nya di atas ambang batas tolensi aman dikonsumsi.

Kata kunci : sampah, TPA, plumbum, merkuri, sapi potong

\section{A Study of Potential of Rubbish and Heavy Metal Residues in Beef Cattle Product Which is Grazing in Refusal Place of "PUTRI CEMPO" Surakarta}

\begin{abstract}
ABSRACT
The aim of this research is to determine the potential of rubbish (quantity and quality) as cattle feeding and the heavy metal residues especialy $\mathrm{Pb}$ and $\mathrm{Hg}$ in beef cattle product (meat and viceral organ) wich is grazing in refusal place "Putri Cempo" Surakarta.

The experiment have been carried out at refusal place "Putri Cempo" Surakarta where samples taken for quantity and quality of organic rubbish and beef catlle product for determine of heavy metal residues ( $\mathrm{Pb}$ and $\mathrm{Hg}$ ) especialy on meat (biceps femoris), liver, kidney and intestine.
\end{abstract}


The result of this experiment indicated that organic rubbish at refusal place "Putri Cempo" Surakarta on DM basic, since 2002 - 2006 amount of 47,778 - 54,372 thousants ton/year. While nutrient content such as crude protein 10,00-12,79\%, extract eter 4,05-7,94\%, crude fiber 18,42 - 22,20\%, and ash 21,73 - 24,33\%, respectively. Heavy metal residues on meat, liver, kidney and intestine, $\mathrm{Pb}$ at amount of 2,16-2,68 ppm which is up of the Indonesia National Standart, SNI (2,0 ppm), and Hg at amount of 0,01 -0,02 it is below of SNI (0,03 ppm).

It could be concluded that higly potensitial of refusal place "Putri Cempo" Surakarta as catlle grazing. The other than, beef cattle product (meat) were not save for consumption.

Key words : rubbish, refusal place, plumbum, merkury, cattle

\section{PENDAHULUAN}

Kebutuhan dasar kehidupan manusia pada awalnya hanya berupa pangan, sandang dan papan, kemudian diikuti dengan kebutuhan kesehatan dan pendidikan. Khususnya pada kebutuhan pangan, dengan semakin meningkatnya taraf hidup, kesejahteraan dan tingkat pendidikan, maka pemenuhan kebutuhan pangan dituntut memenuhi kecukupan gizinya. Pola konsumsi yang pada awalnya berkisar pada upaya pemenuhan kebutuhan pangan pokok saja, akan bergeser dan terus berkembang kearah pemenuhan kebutuhan pangan yang bergizi tinggi. Bahan pangan yang bergizi tinggi pada umumnya diperoleh dari produk hewan/ternak (hewani)

Dari beberapa penelitian menunjukkan bahwa bahan pangan hewani memiliki kelebihan dibanding dengan bahan pangan nabati. Bahan pangan hewani mengandung protein dengan komposisi asam amino essensial yang lebih lengkap (Winarno,1995), mengandung lebih banyak vitamin dan mineral yang mudah diserap oleh tubuh seperti misalnya vitamin $\mathrm{A}, \mathrm{B}_{12}$, dan $\mathrm{D}_{3}$, serta mineral $\mathrm{Fe}, \mathrm{Zn}$, Se, $\mathrm{Ca}$ dan $\mathrm{Cu}$, mempunyai nilai cerna protein yang lebih tinggi, dapat meningkatkan produktifitas kerja dan daya tahan tubuh terhadap penyakit. Kelebihan lainnya adalah dapat meningkatkan tingkat kecerdasan seseorang. Hal ini terkait dengan bahan-bahan essensial untuk pemebentukan otak adalah protein berkualitas, lemak dan kolesterol, dimana bahan-bahan tersebut berasal dari bahan pangan hewani. Disamping itu Asetilcholin yang merupakan bahan untuk mensintesa neurotransmiter banyak terdapat pada daging dan telur (Handayanta, 2007)

Mengingat peranan bahan pangan hewani (khususnya daging) tersebut, maka permintaan dan konsumsi daging semakin meningkat dari waktu ke waktu, dan untuk memenuhinya, maka diperlukan peningkatan produktifitas ternak-ternak penghasil daging. Salah satu ternak yang potensial sebagai penghasil daging adalah sapi potong. Pemerintah melalui Ditjen Produksi Peternakan telah mencanangkan program swasembada daging tahun 2010 dengan tujuan meningkatkan ketersediaan daging sapi untuk memenuhi permintaan konsumsi masyarakat, mengurangi ketergantungan impor daging dan sapi serta meningkatkan efisiensi dan efektifitas usaha budidaya ternak sapi (Luthan, 2007)

Dalam pengembangan populasi sapi potong, daya dukung pakan adalah sangat penting, mengingat pakan merupakan faktor utama yang menentukan produktifitas serta biaya produksinya. Pakan dibutuhkan oleh sapi potong, karena kandungan nutrien di dalamnya diperlukan untuk membangun jaringan baru dan meggantikan jaringan atau bagian-bagian tubuh yang rusak (Cullison, 1979)., untuk hidup pokok, pertumbuhan, produksi dan reproduksi (Tillman et al., 1995). Lebih lanjut dijelaskan bahwa faktorfaktor yang mempengaruhi kebutuhan nutrien 
ternak antara lain tingkat pertumbuhan, ukuran ternak, jenis ternak, keturunan, lingkungan, penyakit, derajat perlemakan dan keserasian gizi pakan. Ternak dapat berproduksi tinggi apabila mendapatkan pakan yang sempurna atau seimbang yang mengandung semua nutrien yang dibutuhkan untuk memenuhi kebutuhan ternak (sapi potong) akan energi, protein, mineral, vitamin dan air. Disisi lain diketahui bahwa biaya pakan dapat mencapai $70-80$ persen dari biaya produksi. Oleh karenanya berbagai upaya telah dilakukan dalam mencari alternatif budidaya sapi potong dengan menggunakan pakan yang seefisien mungkin. Salah satunya adalah pemeliharaan/penggembalaan sapi potong di Tempat Pembuangan Akhir (TPA) sampah.

Sampah yang dibuang ke TPA menurut Bahar (1986), dikelompokkan menjadi 3 golongan berdasarkan asalnya, yakni sampah yang berasal dari kegiatan rumah tangga (domistic refuse), berasal dari kegiatan perdagangan (commercial refuse) dan yang berasal dari kegiatan perindustrian (industrial refuse). Sedangkan menurut Irawati, (1999) sampah dikelompokan menjadi 3 golongan berdasarkan pengelolanya, yakni sampah domistik yakni sampah yang dikelola oleh Dinas Kebersihan Perkotaan (DKP), sampah pasar yakni sampah yang dikelola oleh Dinas Pengelolaan Pasar (DPP) dan sampah umum yakni sampah yang dikelola oleh masyarakat secara mandiri. Hasil penelitian Irawati (1999), menunjukkan bahwa jumlah sampah yang dibuang ke TPA "Putri Cempo" yang berlokasi di Mojosongo Surakarta yang dapat dimakan (edible) oleh sapi, rata-rata sebesar $30.920,1 \mathrm{Kg} /$ hari yang masing masing terdiri dari sampah domistik $19.225,52 \mathrm{Kg}$, sampah pasar 10.419,46 Kg dan sampah umum $1.275,12 \mathrm{Kg}$.

Kenyataan di lapangan menunjukkan bahwa TPA sampah "Putri Cempo", Surakarta telah dimanfaatkan sebagai tempat penggembalaan sapi potong. Lebih dari 1000 ekor sapi potong digembalakan di lokasi TPA tersebut setiap hari. Kegiatan penggembalaan sapi di TPA sampah dapat memberikan keuntungan yakni dapat memanfaatkan barang yang sudah tidak berguna (sampah) menjadi produk yang lebih bermanfaat dan memiliki nilai ekonomis tinggi (daging sapi) yang merupakan sumber protein hewani serta dapat meningkatkan pendapatan peternak melalui kepemilikan sapi potong.

Tetapi disisi lain keamanan pangan (daging) dari sapi yang digembalakan di lokasi TPA sampah diragukan keamannya karena dicurigai terkontaminasi logam berat. Mengingat TPA sebagai tempat pembuangan berbagai macam sampah yang kemungkinan mengandung logam berat, sehingga apabila terkonsumsi oleh sapi akan terakumulasi di dalam tubuh (daging) sapi yang pada konsentrasi yang tinggi (melebihi ambang batas) akan membahayakan kosumen yang mengkonsumsi daging sapi tersebut. Karena residu logam berat dalam tubuh bersifat akumulatif dan berbahaya bagi kesehatan (Sinaga, 2004). Senyawa beracun yang berasal dari residu yang berbahaya bagi kesehatan tubuh yang dikenal dengan istilah bahan berbahaya dan beracun (B3) adalah logam berat. Beberapa logam berat keberadaanya tidak berguna bagi tubuh, bahkan berpotensi meracun bila konsentrasinya tinggi. Beberapa residu utama logam berat diantaranya adalah Timbal atau Plumbum (Pb), Merkury atau Hydrogyrum $(\mathrm{Hg})$, Kadmium (Cd) dan Arsen (As) (Anonimus, 2004)

Namun demikian beberapa penelitian yang telah dilakukan memberikan hasil yang berbeda. Di Jawa Barat, sapi-sapi yang digembalakan di TPA sampah Ciangir Tasikmalaya, terbukti tidak tercemar logam berat (Anonimus. 2006 ${ }^{\mathrm{a}}$ ), sedangkan di Semarang sapi-sapi yang digembalakan di TPA sampah Jatibarang tercemar logam berat khususnya Timbal $(\mathrm{Pb})$ (Anonimus. 2006 ${ }^{\mathrm{b}}$ ). Keadaan ini membuktikan bahwa adanya 
perbedaan kandungan logam berat yang terkandung di dalam daging sapi yang digembalakan di loksai TPA sampah yang berbeda. Hal ini diduga karena adanya pebedaan karakteristik sampah yang dibuang di lokasi TPA sampah.

Berdasarkan hal tersebut diatas, maka perlu dilakukan penelitian (studi) tentang kandungan logam berat yang terdapat dalam daging sapi-sapi yang digembalakan di lokasi TPA sampah " Putri Cempo" Mojosongo Surakarta.

\section{METODE PENELITIAN}

\section{Lokasi dan Waktu Penelitian}

Penelitian ini telah dilaksanakan di beberapa lokasi antara lain 1) TPA sampah "Putri Cempo" Mojosongo Surakarta, 2) Desa Jatirejo, Mojosongo, Surakarta lokasi kelompok peternak sapi potong, yang sapisapinya diambil sampel produknya 3) Laboratorium Biokimia Nutrisi Fakultas Peternakan UGM untuk analisis proksimat (kandungan nutrien) sampel sampah (organik), 4). Rumah Potong Hewan (RPH) Kota Surakarta, lokasi dimana sapi-sapi dipotong untuk diambil sampel produknya, 5) Laboratorium Kimia Analitik, Pusat Teknologi Akselerator dan Proses Bahan, BATAN Yogyakarta untuk analisis kandungan logam berat $(\mathrm{Pb}$ dan $\mathrm{Hg})$ pada daging, hati, ginjal dan usus sapi. Pelaksanaan penelitian dilakukan secara bertahap diantaranya adalah : pengambilan sampel (sampling) sampah, pemilihan sapi yang akan dipotong, analisis sampel sampah (organik) dan kandungan logam berat dalam daging, hati, ginjal dan usus sapi.

\section{Materi Penelitian}

1. Sapi

Digunakan sapi potong jantan yang telah biasa digembalakan di TPA
"Putri Cempo" sebanyak 3 (tiga) ekor, umur berkisar 1,5 - 3 tahun.

2. Seperangkat peralatan untuk pengabilan sampel sampah antara lain : pakaian lapangan (wear pack, masker, sepatu booth, sarung tangan), keranjang sampah, kantong-kantong palstik dan lembaran plastik.

3. Timbangan

Timbangan yang digunakan dalam penelitian ini adalah untuk menimbang sampel sampah.

4. Seperangkat alat dan kemikalia untuk analisis proksimat sampel sampah (organik), dan analisis kandungan logam berat $(\mathrm{Pb}$ dan $\mathrm{Hg})$ dalam daging, hati, ginjal dan usus sapi.

\section{Metode}

1. Persiapan penelitian

Persiapan penelitian dilakukan dengan cara survey ke lokasi untuk menentukan cara dan waktu pengambilan sampel sampah yang dibuang ke TPA, serta menetapkan sapi-sapi yang akan dipotong untuk diambil sampel daging, hati, ginjal dan ususnya

2. Pengambilan sampel sampah

Pengambilan sampel sampah dibedakan menurut jenisnya. Sampah domistik yakni sampah yang dikelola oleh Dinas Kebersihan Perkotaan (DKP), sampah pasar yakni sampah yang dikekola Dinas Pengelolaan Pasar (DPP) dan sampah umum yakni sampah yang dikelola oleh masyarakat umum secara mandiri. Waktu pengambilan sampel sampah dilakukan 7 (tujuh) hari efektif dari hari Senin sampai Minggu. Dari setiap jenis sampah tersebut diambil sebesar 20 persen dari frekuensi pembuangan yang dilakukan yang menggunakan armada (colt dan atau truk). Untuk 
armada truk diambil $50 \mathrm{Kg}$ dan untuk colt diambil $25 \mathrm{Kg}$. Sampel sampah yang diperoleh dipisahkan antara sampah organik (edible) dengan sampah anorganik (non edible). Dari sampel sampah organik (edible) diambil 10 persen untuk dikeringkan dan dilakukan komposit sebelum dilakukan analisis proksimat.

3. Pengambilan data kandungan Logam Berat

Kandungan logam berat khususnya Plumbum $(\mathrm{Pb})$ dan Mercuri $(\mathrm{Hg})$ diambil dari 3 (tiga) ekor sapi yang pemotongannya dilakukan di RPH milik Dinas Pertanian Kota Surakarta. Sampel dari bagian sapi yang diambil adalah daging bagian Longissimus dorsi (LD), hati, ginjal dan usus

4. Analisis Hasil

Semua data yang diperoleh yakni, jumlah dan kualitas sampah (organik), serta kandungan $\mathrm{Pb}$ dan $\mathrm{Hg}$ dalam daging, hati ginjal dan usus sapi dianalisis dan dilaporkan secara deskriptif.

\section{HASIL DAN PEMBAHASAN}

\section{Potensi Sampah sebagai Pakan}

Tempat pembuangan akhir (TPA) sampah "Putri Cempo" berlokasi di Desa Jatirejo, Mojosongo, Kota Surakarta. Total areal TPA seluas $17 \mathrm{Ha}$, yang terdiri dari areal untuk kantor, bengkel, jalan dan yang efektif untuk pembuangan sampah seluas 13 Ha. Tempat pembuangan akhir (TPA) "Putri Cempo" Mojosongo didirikan/dibuka sejak tahun 1986. Berdasarkan pengelolanya, sampah yang dibuang ke TPA "Putri Cempo" dikelompokkan menjadi 3 (tiga) kelompok, yakni sampah domistik yang dikelola oleh Dinas Kebersiahan dan Pertamanan (DKP), sampah pasar yang dikelola oleh Dinas Pengelolaan Pasar dan sampah umum yang dikelola/dibuang oleh masyarakat umum secara mandiri langsung ke TPA (Irawati, 1999).

Berdasarkan hasil pengambilan sampel (sampling) sampah yang dibuang ke TPA "Putri Cempo" dan dipisahkan antara sampah organik dan sampah anorganik, terlihat bahwa jumlah sampah organik jauh lebih banyak daripada yang anorganik (tabel 1). Jumlah sampah organik dari masingmasing sumber sampah yang dibuang di TPA, diantaranya DKP $(63,82 \%)$, DPP $(83,21 \%)$ dan umum (67,53\%). Dari jumlah sampah organik tersebut, jenis/macam sampah yang dominan dari DKP (daun pisang, daun pohon-pohonan perdu dan kulit jeruk), dari DPP ( daun bawang merah, daun bawang putih dan daun pisang) dan untuk sampah umum (daun pisang, daun pohon-pohonan perdu dan kulit pisang). Sedangkan jenis sampah anorganik yang dibuang ke TPA dari ketiga sumber/pengelola pembuangan sampah yang dominan adalah plastik, kertas dan kain.

Berdasarkan hasil sampling di atas, maka potensi jumlah sampah organik yang dibuang ke TPA "Putri Cempo" selama 5 (lima) tahun terakhir seperti terlihat pada Tabel 1 berikut.

Dari tabel 1 terlihat bahwa jumlah sampah yang dibuang ke TPA "Putri Cempo" paling besar adalah sampah domistik yang dikelola oleh DKP, diikuti oleh sampah pasar yang dikelola DPP dan paling sedikit adalah sampah umum. Selama kurun 5 (lima) tahun terakhir, jumlah sampah organik yang dibuang ke TPA, untuk sampah domistik berkisar 40,033 - 44,001, sampah pasar berkisar 6,454 - 8,684, dan sampah umum 1,230 - 1,686 masing-masing dalam ribu ton. Sehingga total sampah organik yang dibuang ke TPA berkisar antara 47, 778 - 54, 372 ribu ton /tahun. Suatu jumlah yang sangat besar, yang apabila tidak dikelola sangat berpotensi sebagai bahan pencemar/polutan. Namun demikian dibalik potensi yang besar ini apabila dapat dimanfaatkan sebagai pakan 
ternak, khususnya sapi potong maka akan diperoleh keuntungan ganda (multiplier efect) yakni disatu sisi dapat mengurangi terjadinya pencemaran/polusi disisi lain dapat dipakai sebagai pakan sapi potong.

Tabel 1. Jumlah sampah yang dibuang di TPA "Putri Cempo" Mojosongo selama 5 tahun terakhir (ribu ton)

\begin{tabular}{|c|c|c|c|c|c|c|}
\hline \multirow{2}{*}{$\begin{array}{l}\text { Sumber } \\
\text { sampah }\end{array}$} & \multirow{2}{*}{$\begin{array}{c}\text { Jenis } \\
\text { sampah }\end{array}$} & \multicolumn{5}{|c|}{ Tahun } \\
\hline & & 2002 & 2003 & 2004 & 2005 & 2006 \\
\hline \multirow{2}{*}{ Domistik } & Total & 62,728 & 66,918 & 68,572 & 68,945 & 65,935 \\
\hline & Organik & 40,033 & 42,707 & 43,763 & 44,001 & 42,080 \\
\hline \multirow{2}{*}{ Pasar } & Total & 7,756 & 9,605 & 10,131 & 10,437 & 10,347 \\
\hline & Organik & 6,454 & 7,992 & 8,430 & 8,684 & 8,610 \\
\hline \multirow{2}{*}{ Umum } & Total & 1,912 & 2,305 & 2,322 & 2,497 & 1,821 \\
\hline & Organik & 1,291 & 1,557 & 1,568 & 1,686 & 1,230 \\
\hline Total sampah & Organik & 47,778 & 52,256 & 53,761 & 54,372 & 51,920 \\
\hline
\end{tabular}

Sumber : Data sekunder DKP Kota Surakarta (2007)

\section{Kandungan Nutrien Sampah Organik}

Hasil analisis proksimat sampah organik yang dibuang di TPA "Putri Cempo"
Mojosongo seperti terlihat pada Tabel 2 berikut.

Tabel 2. Kandungan Nutrien Sampah Organik TPA "Putri Cempo" Mojosongo (\%)

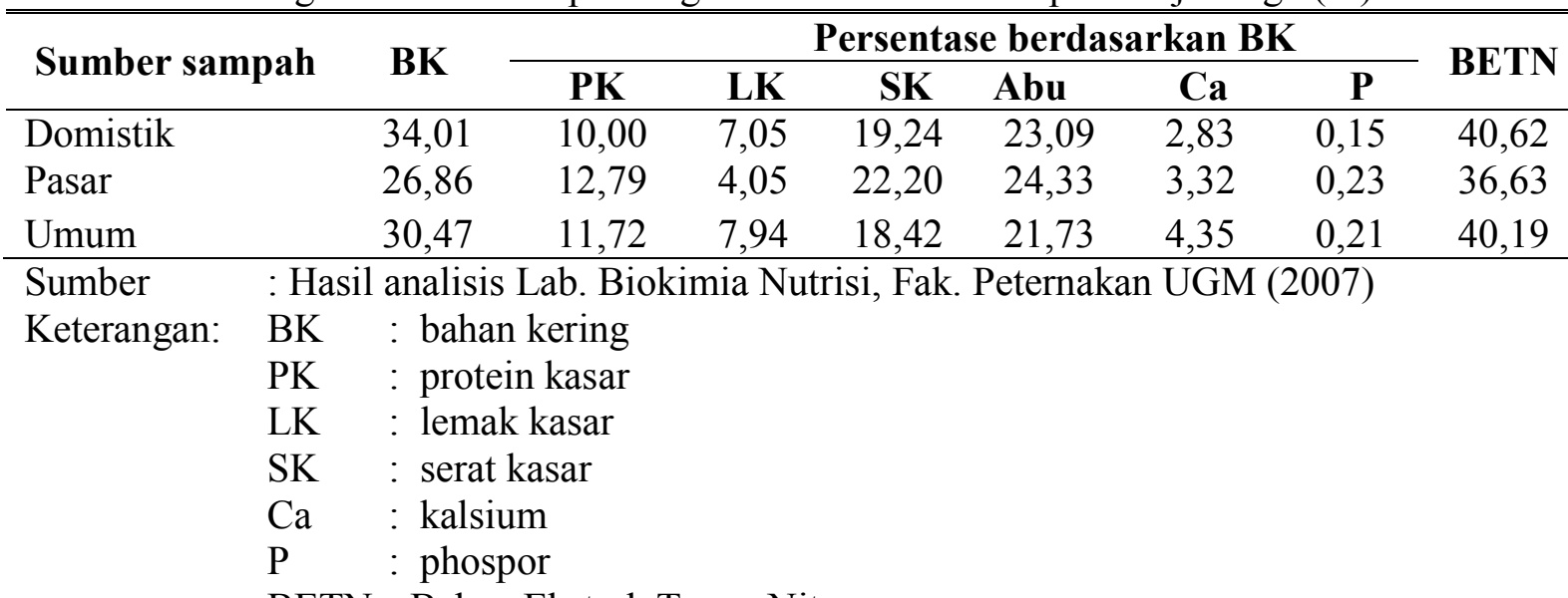

BETN : Bahan Ekstrak Tanpa Nitrogen

Dari hasil analisis proksimat sampah organik terlihat bahwa kandungan PK berkisar antara 10,00 - 12,79\% dan SK 18,42 - 22,20\%. Berdasarkan kandungan PK dan SK tersebut, sampah organik ini lebih baik daripada hijauan jenis rumput-rumputan, seperti rumput lapangan dengan PK 6,7\% dan SK 34,2\%, rumput Gajah PK 9,6\% dan SK $32,7 \%$, maupun hijauan dari limbah pertanian seperti jerami padi dengan PK 4,5\% dan SK
35,5\%, pucuk tebu PK 4,9\% dan SK 33,5\%, jerami jagung $\mathrm{PK}$ 9,3\% dan SK 25,6\% (Siregar, 1994). bahkan kandungan protein kasar sampah organik yang berasal dari sampah pasar $(12,79 \%)$ sedikit lebih tinggi daripada konsentrat komersial BC 133 untuk sapi potong yakni sebesar 12,24 \% (Sudrajat, 2006).

Berdasarkan kandungan bahan kering (BK)-nya, maka total BK sampah organik 
selama 5 (lima) tahun $(2002$ - 2006) adalah berkisar antara 14,55 - 16,56 ribu ton/tahun. Bila diasumsikan bakalan sapi potong yang digemukan dengan bobot badan $300 \mathrm{Kg}$ /ekor dan kemampuan mengkonsumsi pakan (dalam BK) sebesar 3\% bobot badan (NRC, 1976), adalah $9 \mathrm{Kg} /$ ekor/hari atau 3.285 $\mathrm{Kg} /$ ekor/tahun, maka sampah organik tersebut dapat mencukupi 4429 - 5041 ekor. Suatu potensi yang cukup besar yang dapat mendukung upaya peningkatan populasi dan produktifitas sapi potong dalam rangka mendukung program pemerintah terkait program swasembada daging 2010 (Luthan, 2007). Bahkan dilihat dari sisi ekonominya, usaha peternakan di tempat sampah adalah sangat ekonomis, karena biaya pakan relatif tidak ada, kecuali bila peternak memberikan pakan tambahan. Padahal seperti diketahui bahwa biaya pakan merupakan biaya terbesar dalam usaha peternakan termasuk pemeliharaan sapi potong.

\section{Kandungan Residu Logam Berat}

Munculnya berbagai penyakit akibat kontaminasi logam berat adalah karena toksikan logam berat tersebut mempunyai kemampuan berikatan dengan enzim dengan cara menggantikan gugus logam yang berfungsi sebagai kofaktor enzim. Oleh karena itu enzim menjadi terganggu fungsinya, sehingga menyebabkan terganggunya proses metabolisme sebagai akibat sistem fisiologi yang tidak seimbang.

Senyawa Timbal atau Plumbum $(\mathrm{Pb})$ dan Merkury atau Hydrogyrum (Hg) merupakan senyawa logam berat yang terdapat di alam dan berbahaya bagi kesehatan manusia bila terkonsumsi. Hal ini terjadi karena logam berat dalam tubuh bersifat akumulatif (Sinaga, 2004).

Senyawa logam berat banyak dipakai di dalam kegiatan industri khususnya pertambangan dan ataupun sebagai campuran dalam pembuatan alat-alat rumah tangga seperti alat-alat elektronik, plastik, cat, pewarna, bensin, mainan anak-anak, dan lainlain. Senyawa logam berat masuk ke dalam tubuh melalui makanan, minuman, udara dan air yang terkontaminasi logam berat tersebut.

Kandungan Plumbum $(\mathrm{Pb})$ dan Hydrogyrum $(\mathrm{Hg})$ dalam produk sapi potong yang digembalakan di TPA "Putri Cempo" Mojosongo seperti terlihat pada Tabel 3 dan Tabel 4 berikut.

Tabel 3. Kandungan Plumbum $(\mathrm{Pb})$ dalam organ sapi potong yang digembalakan di TPA "Putri Cempo" Surakarta (ppm)

\begin{tabular}{|c|c|c|c|c|c|}
\hline \multirow{2}{*}{ Organ } & \multicolumn{3}{|c|}{ Sapi } & \multirow{2}{*}{ Rata-rata } & \multirow{2}{*}{$\begin{array}{c}\text { SNI } \\
\text { (ppm) }\end{array}$} \\
\hline & 1 & 2 & 3 & & \\
\hline Daging & 2,1597 & 2,0742 & 2,2450 & 2,1596 & 2,0 \\
\hline Ginjal & 2,2625 & 2,2587 & 2,3444 & 2,2885 & 2,0 \\
\hline Hati & 2,6101 & 2,5157 & 2,4088 & 2,5115 & 2,0 \\
\hline Usus & 2,6832 & 2,6866 & 2,6609 & 2,6769 & 2,0 \\
\hline
\end{tabular}

Sumber : Hasil analisis Laboratorium Kimia Analitik, Pusat Teknologi Akselerator dan Proses Bahan, Batan Yogyakarta (2007)

Dari tabel 3 terlihat bahwa kandungan Plumbum $(\mathrm{Pb})$ produk ( organ) sapi potong yang digembalakan di TPA "Putri Cempo" Mojosongo berturut-turut untuk sapi 1, 2 dan 3 masing masing untuk daging, adalah 2,$1597 ; 2,0742$, dan 2,2450 ppm, ginjal adalah
2,$2625 ; 2,2587$, dan 2,3444 ppm, hati adalah 2,$6101 ; 2,5157$, dan 2,4088 ppm, dan usus adalah 2,6832, 2,6866, dan 2,6609 ppm. Sedangkan untuk rata-rata dalam daging 2,1596 ppm, ginjal 2,2885 ppm, hati 2,5115 ppm dan usus 2,6769 ppm. 
Kandungan Plumbum $(\mathrm{Pb})$ dalam produk (organ) sapi potong hasil analisis tersebut semua di atas ambang batas toleransi yang bisa (aman) dikonsumsi sesuai Standar Nasional Indonesia (SNI) yang menyatakan kandungan $\mathrm{Pb}$ makanan atau minuman maksimal $0,3 \mathrm{mg} / \mathrm{Kg}(0,3 \mathrm{ppm})$. Dengan kata lain bahwa produk sapi potong yang digembalakan di TPA "Putri Cempo" Mojosongo kurang aman untuk dikonsumsi.

Tingginya kandungan $\mathrm{Pb}$ dalam produk (organ) sapi yang digembalakan di TPA kemungkinan karena sampah terkontaminasi dengan senyawa-senyawa $\mathrm{Pb}$. Hal ini terlihat dari hasil sampling jenis/macam sampah (anorganik) yang di buang di TPA "Putri Cempo" yang didominasi oleh sampah plastik, kertas (koran) dan kain. Ketiga bahan tersebut berpotensi sebagai pencemar karena senyawa logam digunakan dalam proses pembuatan barang-barang tersebut. Plastik, kertas koran (tintanya) dan kain (zat pewarnanya) semuanya mengandung senyawa $\mathrm{Pb}$ (Winarno, 2004).

Tabel 4. Kandungan Hydrogyrum (Hg)) dalam organ sapi potong yang digembalakan di TPA "Putri cempo" (ppm)

\begin{tabular}{|c|c|c|c|c|c|}
\hline \multirow{2}{*}{ Organ } & \multicolumn{3}{|c|}{ sapi } & \multirow{2}{*}{ Rata-rata } & \multirow{2}{*}{$\begin{array}{c}\text { SNI } \\
\text { (ppm }\end{array}$} \\
\hline & 1 & 2 & 3 & & \\
\hline Daging & 0,0133 & 0,0095 & 0,0099 & 0,0109 & 0,03 \\
\hline Ginjal & 0,0154 & 0,0151 & 0,0156 & 0,0154 & 0,03 \\
\hline Hati & 0,0157 & 0,0158 & 0,0163 & 0,0159 & 0,03 \\
\hline Usus & 0,0237 & 0,0214 & 0,0223 & 0,0225 & 0,03 \\
\hline
\end{tabular}

Sumber : Hasil analisis Laboratorium Kimia Analitik, Pusat Teknologi Akselerator dan Proses Bahan, Batan Yogyakarta (2007)

Dari tabel 4 terlihat bahwa kandungan Hydrogyrum ( $\mathrm{Hg}$ ) produk (organ) sapi potong yang digembalakan di TPA "Putri Cempo" Mojosongo berturut-turut untuk sapi 1,2 dan 3 masing masing untuk daging, adalah 0,$0133 ; 0,0095$ dan $0,0099 \mathrm{ppm}$, ginjal adalah 0,$0154 ; 0,0151$ dan 0,0156 ppm, hati adalah 0,$0157 ; 0,0158$ dan 0,0163 ppm, dan usus adalah 0,$0237 ; 0,0214$ dan $0,0223 \mathrm{ppm}$. Sedangkan untuk rata-rata dalam daging 0,0109 ppm, ginjal 0,0154 ppm, hati $0,0159 \mathrm{ppm}$ dan usus $0,0225 \mathrm{ppm}$. Kandungan Hydrogyrum $(\mathrm{Hg})$ dalam produk sapi potong hasil analisis tersebut masih di bawah ambang batas toleransi yang bisa (aman) dikonsumsi sesuai Standar Nasional Indonesia (SNI) yang menyatakan kandungan $\mathrm{Hg}$ makanan atau minuman maksimal 0,03 $\mathrm{mg} / \mathrm{Kg}(0,03 \mathrm{ppm})$. Artinya, dengan melihat kandungan $\mathrm{Hg}$ saja sebenarnya produk sapi potong layak (aman) dikonsumsi. Akan tetapi karena kandungan $\mathrm{Pb}$ yang tinggi menjadikan produk tidak aman dikonsumsi. Oleh karena itu, agar produk aman dikonsumsi tinggal diupayakan untuk penurunan kandungan $\mathrm{Pb}$ dalam produk.

Rendahnya kandungan residu $\mathrm{Hg}$ dalam produk (organ) sapi potong yang digembalakan di TPA, kemungkinan karena kontaminan senyawa $\mathrm{Hg}$ dalam sampah rendah. Seperti diketahui bahwa kontaminasi senyawa $\mathrm{Hg}$ banyak terjadi di daerah pertambangan (tailing), mengingat senyawa ini banyak digunakan dalam kegiatan penambangan.

Dari keempat produk (organ) sapi tersebut terlihat bahwa kandungan residu logam berat $(\mathrm{Pb}$ dan $\mathrm{Hg})$, usus adalah yang paling tinggi diikuti hati, ginjal dan yang paling rendah adalah dalam daging. Hal ini sesui dengan fungsi fisiologis dari masingmasing organ sebagai detoksikasi bendabenda asing yang masuk ke dalam tubuh. 


\section{KESIMPULAN DAN SARAN}

\section{Kesimpulan}

Kesimpulan yang diperoleh dari hasil penelitian ini adalah bahwa Tempat Pembuangan (TPA) sampah "Putri Cempo" Surakarta memiliki potensi yang cukup besar sebagai sarana penggembalaan ternak sapi potong, mengingat jumlah sampah organik yang dibuang ke TPA yang secara kuantitatif cukup besar (14,55 - 16,56 ribu ton/tahun) dan secara kaulitatif masih mengandung nutrien yang cukup baik dan dapat dimanfaatkan oleh sapi potong.

Kandungan residu logam berat $\mathrm{Pb}$ dalam produk sapi potong yang digembalakan di TPA "Putri cempo" di atas ambang batas toleransi untuk dikonsumsi, sedangkan untuk $\mathrm{Hg}$ masih dibawah ambang batas toleransi yang aman untuk dikonsumsi.

\section{Saran}

Oleh karena potensi TPA sebagai tempat penggembalaan sapi cukup besar, akan tetapi karena produknya (daging) tidak aman untuk dikonsumsi, maka diperlukan penelitian lebih lanjut untuk mencari metode/cara untuk menurunkan kandungan $\mathrm{Pb}$ dalam produk sapi potong tersebut.

\section{DAFTAR PUSTAKA}

Anonimus. 2004. Bahaya Cemaran Logam Berat. Pikiran Rakyat, 29 Juli 2004.

Anonimus. 2006 ${ }^{\mathrm{a}}$. Sapi Tercemar Logam Berat. Kompas, 18 September 2006.

Anonimus. 2006 ${ }^{\mathrm{b}}$. Dites, Darah dan Daging Sapi di Sekitar TPA Ciangir. Kompas, 2 Nopember 2006.

Bahar, Y.H. 1986. Teknologi Penanganan dan Pemanfaatan Sampah. PT.Waca Utama Pramesti. Jakarta.

Cullison, A.E. 1979. Feed and Feeding. 2nd eds. Reston Publ. Co., Ic. Reston, Virginia.
Handayanta, E. 2007. Pemahaman terhadap peran dan fungsi kholesterol dalam rangka kampanye kecukupan gizi melalui konsumsi produk hewani. Caraka Tani. Jurnal

ilmu-ilmu PertanianFakultas Pertanian UNS 22 (1) : 42 - 45

Irawati, D.A. 1999. Kinerja Sapi Peranakan Ongole yang Digembalakan di Lokasi Tempat Pembuangan Akhir Mojosongo Surakarta. Tesia S-2. Program Pasca Sarjana UGM. Yogyakarta.

Luthan, F. 2007. Kebijakan Umum Pemberdayaan Masyarakat Perdesaan Indonesia. Seminar Nasional "Peternakan dan Pemberdayaan Masyarakat Perdesaan" Dalam rangka Dies Natalis Fapet UGM ke 38. Yogyakarta.

NRC, 1976. Nutrient Requirement of Beef Cattle. 5th eds. National Academy of Sciences. Washington.

Sinaga, S.M. 2004. Perspektif Pengawasan Makanan dalam Kerangka Keamanan Makanan dan untuk Meningkatkan Kesehatan. Pidato Pengukuhan Jabatan Guru Besar Tetap F.MIPA. USU. Medan

Siregar, S.B. 1994. Pakan ternak Ruminansia. Penebar Swadaya. Jakarta

Sudrajad, A. 2006. Pengaruh Tingkat Suplementasi Virgin Coconut Oil (VCO) dalam Ransum terhadap Performan Sapi Perah PFH Laktasi. Skripsi S 1 Jurusan Peternakan Fak. Pertanian UNS. Surakarta.

Tillman, A.D., H.Hartadi dan R. Reksohadiprodjo, $1995 . \quad$ Ilmu Makanan Ternak Dasar. Gadjah Mada Univ. Press. Yogyakarta.

Winarno, F.G. 1995. Kimia Pangan dan Gizi. Gramedia. Jakarta.

Winarno, F.G. 2004. Keamanan Pangan. MBrio Press. Bogor. 